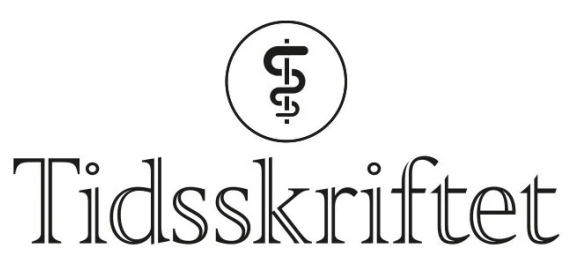

DEN NORSKE LEGEFORENING

\title{
Er koronavaksine til alle en feilsatsing?
}

DEBATT

\section{AMANDA HYLLAND SPJELDNAES}

amanda.spjeldnas@medisin.uio.no

Amanda Hylland Spjeldnæs er medisinstudent og forskerlinjestudent ved Institutt for helse og samfunn ved Universitetet i Oslo.

Forfatteren har fylt ut ICMJE-skjemaet og oppgir ingen interessekonflikter.

\section{Mens vi krangler om den globale vaksinefordelingen, dør langt flere av andre sykdommer enn av korona. Er global helse-feltet på feil spor?}

For femti år siden mente eksperter i global helse at feltet fokuserte for mye på infeksjonssykdommer, på bekostning av arbeid for tilgang på mer grunnleggende ressurser som rent drikkevann og mat (1). Er det tilfellet fremdeles?

\section{Vertikale programmer}

Arbeid i global helse som kun dreier seg om enkeltsykdommer, kalles vertikale programmer. Det kan for eksempel være klinikker som kun tar imot og behandler pasienter med malaria, eller kampanjer for å utrydde spesifikke sykdommer (므). Enkeltsykdommene som vertikale programmer retter seg mot, er med fa unntak infeksjonssykdommer. Dette gir inntrykk av at verden er todelt: Rike land har livsstilssykdommer, og fattige land har infeksjonssykdommer. Sånn er det ikke. Ikkesmittsomme sykdommer står for $71 \%$ av alle dødsfall i verden, og $77 \%$ av dødsfallene som skyldes ikke-smittsomme sykdommer, skjer i lav- og mellominntektsland (3). De vanligste ikke-smittsomme sykdommene som gir død, er hjertesykdom og kreft, og disse sykdommene er multifaktorielle. Vertikale programmer er lite egnet til å løse problemene med de mer komplekse ikke-smittsomme sykdommene, som utgjør det meste av sykdomsbyrden også i lavinntektsland.

Vertikale programmer mangler ofte lokal forankring, og det er sjelden de styrker lokal infrastruktur (4.), s. 43-88). Programmene er gjerne kortvarige, som innebærer at det er begrenset tid til å etablere nettverk i lokalbefolkningen, og at hjelpearbeiderne jobber parallelt med lokale helsearbeidere, istedenfor sammen med. Et eksempel er malariakampanjen til Verdens helseorganisasjon (WHO) i 1950- og -6o-årene, der 
kampanjen i de fleste land ble satt opp parallelt med de lokale helsemyndighetenes tiltak, noe som førte til unødvendig overlapp og dårlig prioritering av ressurser ((4.), s. 57-9). En annen konsekvens av manglende lokal forankring er fravær av forståelse for de lokales behov. Et eksempel fra Mosambik viser hvordan pasienter fikk hivmedisiner, men fortsatt sultet i matmangel og hadde andre, mer akutte behov enn medisiner, behov som helseprogrammet ikke grep fatt i ((5). Lokalbefolkningen sitter ofte ikke igjen med så mye når de vertikale programmene er over, og programmene løser ikke den grunnleggende urettferdigheten som er årsaken til mye fattigdom og lidelse i lavinntektsland.

\section{Opphengt i tall og teknologi}

Globalt helsearbeid i dag har en enorm tro på mål og målbarhet (metrics på engelsk)(ㅁ). Istedenfor å spørre seg i hvilken grad et prosjekt vil gjøre godt for befolkningen, spør aktørene i global helse seg om prosjektet vil kunne produsere målbare resultater. Suksessen til prosjekter bør kunne måles i tall, og idealet er at prosjektene inneholder randomiserte kontrollerte studier for å rapportere om resultatene (7.). Ved å fokusere på tall kan ikke-målbare verdier bli neglisjert. Det blir for eksempel mer populært med vertikale programmer som jobber med og måler forekomsten av enkeltsykdommer, enn komplekse prosjekter som jobber med temaer som vanskeligere kan måles, som likestilling og rettferdighet.

\section{"Interessene til aktørene $i$ de offentlig-private samarbeidene kan ligge $i$} noe helt annet enn å forbedre helse»

Det er også en enorm tro på teknologi. Det er enklere å innføre medisinsk teknologi som hurtigtester, vaksiner, medisiner og myggnetting enn å endre på grunnleggende strukturer i samfunnet. Teknologi er gjerne rettet mot enkelttilstander og er ofte en lettvint løsning som raskt gir målbare resultater, men ikke langvarige forbedringer. Teknologi passer dermed ypperlig med behovet for tall i global helse (7.). For eksempel kan teknologiprosjekter relativt raskt oppnå at $90 \%$ av en gruppe med hivpasienter har fått medisiner, eller at antall matforgiftningstilfeller har gått ned med $50 \%$ etter at håndsprit ble distribuert. Men når disse prosjektene er ferdige, og det ikke lenger deles ut medisiner og håndsprit, går også de gode resultatene tilbake. I tillegg er teknologi knyttet til innovasjon, utvikling og muligheter for økonomisk vekst, som bidrar til at teknologiprosjekter i global helse er attraktive for givere.

\section{WHO har mistet makten}

Flere har uttrykt bekymring for at dagens globale helsearbeid med drøssevis av enkeltstående prosjekter ikke er samkjørt nok $(\underline{1}, \underline{8})$. Mens WHO for noen tiår siden var den ledende aktøren i globalt helsearbeid, har offentlig-private samarbeid (OPS), kjent på engelsk som public-private partnerships, fått en viktig rolle de siste årene (4), s. 141-92, (9). Svært forenklet er dette samarbeid mellom ulike aktører som bidrar med for eksempel penger, organisering, ideer eller arbeidskraft, og aktørene er blant annet banker, teknologiselskaper, organisasjoner, myndigheter og pengefond. Prosjektene preges av at det ikke lenger er folkehelseeksperter som styrer dem. Samarbeidene drives gjerne etter neoliberalistiske verdier og en forretningsmodell. For teknologi- og legemiddelprodusenter er offentlig-private samarbeid en mulighet til å få produktene sine inn på nye markeder i lavinntektsland. For investorer må prosjektene være gunstige å investere $\mathrm{i}$, for eksempel ved at de gir tydelige resultater og $\emptyset$ konomisk gevinst. Interessene til aktørene i de offentlig-private samarbeidene kan med andre ord ligge i noe helt annet enn å forbedre helse. 
Organisasjonenes rolle har endret seg med fremveksten av offentlig-private samarbeid i global helse. Når noen av aktørene er opptatt av at prosjektet skal gi målbare resultater og tjene penger, mens organisasjonsarbeiderne ønsker at prosjektet skal gjøre livet bedre for befolkningen de jobber med, oppstår det interessekonflikter. Prosjekter preges av å måtte tilfredsstille krav fra givere. De utformes for å kunne produsere målbare resultater og legge til rette for økonomisk vekst, og det kan gå på bekostning av organisasjonens verdigrunnlag om for eksempel bærekraft og rettferdighet (9.). Også når pengene til et prosjekt blir innvilget, styres organisasjonene av givere som ofte begrenser organisasjonsarbeidernes jobb. For eksempel møtte en aidsorganisasjon i Nepal et dilemma da giverne til prosjektet stilte krav til måten organisasjonsarbeiderne skulle snakke om hiv på, da den sto i motstrid med arbeidernes og lokalbefolkningens forståelse av sykdommen (무). For å tilfredsstille ønsket om ekspansjon og vekst ønsker givere også gjerne at prosjekter som starter i et lokalmiljø, skaleres opp til å også brukes andre steder i verden. Dette strider ofte mot organisasjonenes ønske om at hvert prosjekt som gjennomføres, skal være tilpasset de spesifikke lokale forholdene (7.).

\section{Koronavaksiner}

Dagens globale kampanje for flere koronavaksiner til lavinntektsland er utvilsomt viktig, men kan også utfordres. Det dør langt flere av andre sykdommer enn av korona. I den offentlige debatten snakker man om tilgang på koronavaksiner som en menneskerett, men hvorfor anses ikke for eksempel tilgang på hjertekirurgi som en menneskerett (11), s. 223)? Det døde tre ganger så mange av hjertesykdom som av korona i verden i 2020 ((12). I gjennomsnitt var korona på 19. plass av rapporterte og 9. plass av estimerte dødsårsaker i Afrika i 2020. I flere europeiske land og USA var derimot korona øverst på listen over dødsårsaker i 2020. Det ser altså ut til at korona har rammet høyinntektsland langt hardere enn lavinntektsland. Selv om vaksinen er nødvendig for at samfunn i nord åpner igjen, er kanskje andre prioriteringer viktigere i andre deler av verden.

\section{"Vaksineringen er et typisk eksempel på et relativt kortvarig vertikalt program med fokus på tall og teknologi»}

Norge bidrar til vaksinefordelingen gjennom COVAX, som er et offentlig-privat samarbeid. Vaksineringen er et typisk eksempel på et relativt kortvarig vertikalt program med fokus på tall og teknologi. Vaksineteknologi distribueres, suksessen måles i hvor mange mennesker som er vaksinert, og når vaksinene er satt, er programmet over. De enorme ressursene som kreves for å sette vaksiner, går kanskje på bekostning av utbygging av infrastruktur i lavinntektsland. Istedenfor at disse landene bruker penger på å sikre trygge boforhold og tilgang på helsetjenester, kjøper de vaksiner. Og nettopp den manglende infrastrukturen gjør vaksinasjonsprogrammet mindre effektivt. Flere afrikanske land mangler for eksempel god nok strømforsyning til å holde vaksinedosene kalde og frakte dem ut til landsbygda (13). Hvis vaksinasjonsprogrammet ikke samtidig bygger ut infrastruktur, er ikke landene noe sterkere eller bedre rustet for neste pandemi etter at vaksinene er satt.

\section{Behov for langsiktige planer}

Dagens kortvarige vertikale programmer med fokus på tall og teknologi maskerer at det er underliggende strukturelle ulikheter som må tas tak i for at lavinntektsland skal få bærekraftige og gode helsesystemer. Misforstå meg rett. Jeg sier ikke at vi skal la være å bekjempe infeksjonssykdommer og jobbe for at lavinntektsland får flere koronavaksiner, 
men bare at dagens strategier ikke er nok. Vi må ha to tanker i hodet samtidig: kortsiktige prosjekter som håndterer akutte kriser, og langsiktige prosjekter som jobber mot bærekraftige helsesystemer i fremtiden.

Her er noen forslag til konkrete steder å starte for å skape gode globale helsetilbud på sikt. Flere prosjekter kan jobbe for global tilgang på primærhelsetjeneste, altså helsetjenester som ser hele pasienten, og som bidrar med forebygging, behandling og omsorg gjennom hele livet (14). Vi kan legge mer ressurser i infrastruktur som sanitærforhold og matsikkerhet. Vi kan starte flere forskningsprosjekter og folkehelsearbeid som retter oppmerksomhet mot ikke-smittsomme sykdommer i lavinntektsland. Samtidig bør vi bli mer bevisste på at dagens opphengthet i tall og teknologi ikke nødvendigvis vil føre til best helse, og heller starte prosjekter som for eksempel måler suksessen gjennom kvalitative intervjuer og ikke gjennom statistikk. Vi kan også styrke organisasjonenes rolle i globalt helsearbeid, for eksempel ved å oppfordre givere til å stille færre krav til organisasjonene de støtter. I tillegg kan vi stå sammen for et sterkt WHO, eller i hvert fall for et sterkt samlende organ i globalt helsearbeid. Vi bør også ha som mål å jobbe med og ikke over hodet på lokalbefolkningen i alle prosjekter. Vi må utfordre dagens global helse-felt for å få til de langsiktige planene som trengs for en rettferdig fordeling av helse i fremtiden.

\section{LITTERATUR}

1. Markel H. Worldly approaches to global health: 1851 to the present. Public Health $2014 ; 128: 124-8$. [PubMed][CrossRef]

2. Moran-Thomas A. A salvage ethnography of the guinea worm. I: Biehl J, Petryna A, red. When people come first: critical studies in global health. Princeton, N.J: Princeton University Press, 2013: 207-239.

3. WHO. Noncommunicable diseases. https://www.who.int/news-room/factsheets/detail/noncommunicable-diseases Lest 21.9.2021.

4. Birn AE, Pillay Y, Holtz TH. Textbook of global health. 4. utg. Oxford: Oxford University Press, 2017.

5. Kalofonos I. All I eat is medicine: Going hungry in Mozambique's AIDS economy. California: University of California Press, 2021.

6. Adams V, Burke NJ, Whitmarsh I. Slow research: thoughts for a movement in global health. Med Anthropol 2014; 33: 179-97. [PubMed][CrossRef]

7. Adams V, Craig SR, Samen A. Alternative accounting in maternal and infant global health. Glob Public Health 2016; 11: 276-94. [PubMed][CrossRef]

8. Skotheim B, Larsen BI, Siem H. Verdens helseorganisasjon og global helse. Tidsskr Nor Legeforen 2011; 131: 1793-5. [PubMed][CrossRef]

9. Gideon J, Porter F. Challenging gendered inequalities in global health: Dilemmas for NGOs:

Debate: challenging gendered inequalities in global health. Dev Change 2016; 47: 782-97. [CrossRef]

10. Pigg SL. On sitting and doing: ethnography as action in global health. Soc Sci Med 2013; 99: 127-34. [PubMed][CrossRef]

11. Jones DS. Broken hearts: the tangled history of cardiac care. Baltimore, MD: John Hopkins University Press, 2013.

12. Troeger C. Just how do deaths due to COVID-19 stack up? Think Global Health 3.6.2021. https://www.thinkglobalhealth.org/article/just-how-do-deaths-due-covid-19-stack Lest 21.9.2021.

13. Mueller B, Robbins R. Where a vast global vaccination program went wrong. The New York Times 2.8.2021. https://www.nytimes.com/2021/o8/o2/world/europe/covax-covid-vaccine-problemsafrica.html Lest 21.9.2021

14. WHO. Primary health care. https://www.who.int/health-topics/primary-health-care\#tab=tab_1 Lest 21.9.2021.

Publisert: 13. desember 2021. Tidsskr Nor Legeforen. DOI: 10.4045/tidsskr.21.0685

Mottatt 29.10.2021, godkjent 7.11.2021.

(C) Tidsskrift for Den norske legeforening 2023. Lastet ned fra tidsskriftet.no 26. april 2023. 
